\title{
Effect of analgesic activity in crude extract and isolated compounds of Tecomaria capensis
}

\author{
K. Venkata Gopaiah', G. Kalyani', G. S. N. Koteswara Rao', E. Tamil Jothi \\ ${ }^{1}$ Department of Pharmaceutics, K L College of Pharmacy, Koneru Lakshmaiah Education Foundation, Deemed \\ to be University, Guntur, Andhra Pradesh, India, ${ }^{2}$ Department of Pharmacology, Devaki Amma Memorial \\ College of Pharmacy, Malappuram, Kerala, India
}

\section{Abstract}

Aim: The leaves of the plant Tecomaria capensis were extracted with different solvents and screened for their analgesic activity. Materials and Methods: The ethyl acetate extract of the plant $T$. capensis has showed the presence of flavonoids, glycosides, steroids, and terpenoids. The analgesic activity of ethyl acetate extract of T. capensis leaves is evaluated by Eddy's hot plate and tail flick method. Results and Discussion: This study demonstrates that ethyl acetate extracts of $T$. capensis have significant analgesic activities. Further, with column chromatography technique, different compounds are isolated from the extract. Among the different compounds, 3, 7-dimethyloct-6-en-1-ol showed a comparable activity to standard. Conclusion: The present investigation indicates the probable use of $T$. capensis extracts in the evaluation of analgesic activity.

Key words: Analgesic activity, 3,7-dimethyloct-6-en-1-ol, Tecomaria capensis

\section{INTRODUCTION}

$\mathrm{F}$ rom the beginning of human civilization, plants are one of the most important sources of medicines. ${ }^{[1]}$ Today, nearly $88 \%$ of the global population turn to plantderived medicines as they are the first line of defense for maintaining health and combating diseases. In the present study, an attempt has been made to enrich the knowledge of analgesic activity of ethyl acetate extract of leaves of Tecomaria capensis (family: Bignoniaceae). It is also known as cape honeysuckle and is a fast growing, scrambling shrub which may grow up to $2-3 \mathrm{~m}$ high and spread $>2.5 \mathrm{~m}$. $T$. capensis is an evergreen plant in warm climate areas but loses its leaves in colder areas. It has pinnately compound leaves that have oval leaflets with blunt teeth. Flowering time for this shrub is very erratic, and often it flowers all year round. Flowers are orange in color. Plant is used as a traditional medicine to relieve pain and sleeplessness. Infusions of dried powdered bark are used for sleeplessness. ${ }^{[2,3]}$ It is included in the list of African plants evaluated for in vitro antiplasmodial activity. ${ }^{[4]}$

\section{MATERIALS AND METHODS}

\section{Plant Collection}

Matured leaves of $T$. capensis were collected in bulk in and around Guntur region, Andhra Pradesh, India. The coarse powder was passed through sieve No. 60. The plant of T. capensis was identified by Professor Dr. S.M. Khasim, Department of Botany and Microbiology, Acharya Nagarjuna University, Guntur, Andhra Pradesh, India. The specimen (No: ANU/00129/2009/ AP) was deposited in the Herbarium of the University Department of Botany and Microbiology for future reference.

\section{Extraction}

The leaves of $T$. capensis were separated from the stalks and thoroughly washed with running tap water and rinsed with

Address for correspondence:

K. Venkata Gopaiah, Department of Pharmaceutics, K L College of Pharmacy, Koneru Lakshmaiah Education Foundation, Deemed to be University, Guntur, Andhra Pradesh, India. Phone: +91-9966337164.

E-mail: venkatgopi8789@gmail.com

Received: $25-11-2018$

Revised: $13-12-2018$

Accepted: 17-12-2018 


\begin{tabular}{|c|c|c|c|c|c|}
\hline \multirow[t]{3}{*}{ Treatment } & \multirow[t]{3}{*}{ Dose } & \multicolumn{4}{|c|}{ Paw jumping/Paw licking time (S) } \\
\hline & & \multirow[t]{2}{*}{ Before } & \multicolumn{3}{|c|}{ After administration of drug } \\
\hline & & & $30 \mathrm{~min}$ & $60 \mathrm{~min}$ & $120 \mathrm{~min}$ \\
\hline Control & $1 \mathrm{ml} / \mathrm{kg}$ & $2.11 \pm 0.03$ & $2.19 \pm 0.07$ & $2.19 \pm 0.07$ & $2.15 \pm 0.03$ \\
\hline Standard (pentazocine) & 10 mg/kg & $2.14 \pm 0.55$ & $5.53 \pm 0.05^{\star *}$ & $8.14 \pm 0.06^{\star *}$ & $11.78 \pm 0.10^{* *}$ \\
\hline Ethyl acetate extract & $100 \mathrm{mg} / \mathrm{kg}$ & $2.18 \pm 0.04$ & $3.13 \pm 0.05^{\star *}$ & $5.83 \pm 0.05^{\star \star}$ & $5.39 \pm 0.04^{\star *}$ \\
\hline Ethyl acetate extract & $200 \mathrm{mg} / \mathrm{kg}$ & $2.12 \pm 0.03$ & $4.13 \pm 0.04^{* *}$ & $7.43 \pm 0.07^{\star *}$ & $7.16 \pm 0.06^{\star *}$ \\
\hline (3R)-3,7dimethyloct-6-en-1-ol & $10 \mathrm{mg} / \mathrm{kg}$ & $2.5 \pm 0.3$ & $5.86 \pm 0.43$ & $7.42 \pm 0.79$ & $8.10 \pm 0.34^{\star \star}$ \\
\hline 1,2,3,9-tetrahydropyrrolo quinazoline-3,7-diol & $10 \mathrm{mg} / \mathrm{kg}$ & $2.18 \pm 0.04$ & $5.24 \pm 0.56$ & $6.56 \pm 0.76$ & $7.90 \pm 0.49^{* *}$ \\
\hline
\end{tabular}

Values are expressed as *Mean \pm SEM $(n=6)$ animals. Statistical significance test is carried out by one-way analysis of variance followed by Dunnett's test. ${ }^{* *} P<0.05$ when compared to control, T. capensis: Tecomaria capensis

Table 2: Effect of ethyl acetate extract and isolated compounds of ethyl acetate extract of $T$. capensis leaves by tail flick method

\begin{tabular}{|c|c|c|c|c|c|}
\hline \multirow[t]{3}{*}{ Treatment } & \multirow[t]{3}{*}{ Dose } & \multicolumn{4}{|c|}{ Basal reaction time (S) } \\
\hline & & \multirow[t]{2}{*}{ Before } & \multicolumn{3}{|c|}{ After administration of drug } \\
\hline & & & $30 \mathrm{~min}$ & $60 \mathrm{~min}$ & $120 \mathrm{~min}$ \\
\hline Control & $1 \mathrm{ml} / \mathrm{kg}$ & $2.50 \pm 0.33$ & $2.80 \pm 0.21$ & $2.90 \pm 0.21$ & $3.10 \pm 0.19$ \\
\hline Standard (pentazocine) & $10 \mathrm{mg} / \mathrm{kg}$ & $2.60 \pm 0.28$ & $5.50 \pm 0.39^{* *}$ & $6.93 \pm 0.72^{\star *}$ & $8.26 \pm 0.59^{* *}$ \\
\hline Ethyl acetate extract & $100 \mathrm{mg} / \mathrm{kg}$ & $2.80 \pm 0.23$ & $4.60 \pm 0.20^{*}$ & $5.70 \pm 0.54^{* *}$ & $7.26 \pm 0.49^{* *}$ \\
\hline Ethyl acetate extract & $200 \mathrm{mg} / \mathrm{kg}$ & $2.40 \pm 0.25$ & $5.00 \pm 0.23^{* *}$ & $6.20 \pm 0.43^{\star *}$ & $7.60 \pm 0.56^{\star *}$ \\
\hline (3R)-3,7-dimethyl oct-6-en-1-ol & 10 mg/kg & $2.60 \pm 0.2$ & $5.00 \pm 0.23^{* *}$ & $6.20 \pm 0.43^{* *}$ & $7.60 \pm 0.56^{* *}$ \\
\hline 1,2,3,9-tetrahydropyrrolo quinazoline-3,7-diol & $10 \mathrm{mg} / \mathrm{kg}$ & $2.40 \pm 0.25$ & $3.70 \pm 0.24^{*}$ & $4.60 \pm 0.20$ * & $5.70 \pm 0.54^{* \star}$ \\
\hline
\end{tabular}

Values are expressed as *Mean \pm SEM $(n=6)$ animals. Statistical significance test is carried out by one-way analysis of variance followed by Dunnett's test. ${ }^{*} P<0.01,{ }^{*} P<0.001$, when compared with control, $T$. capensis: Tecomaria capensis

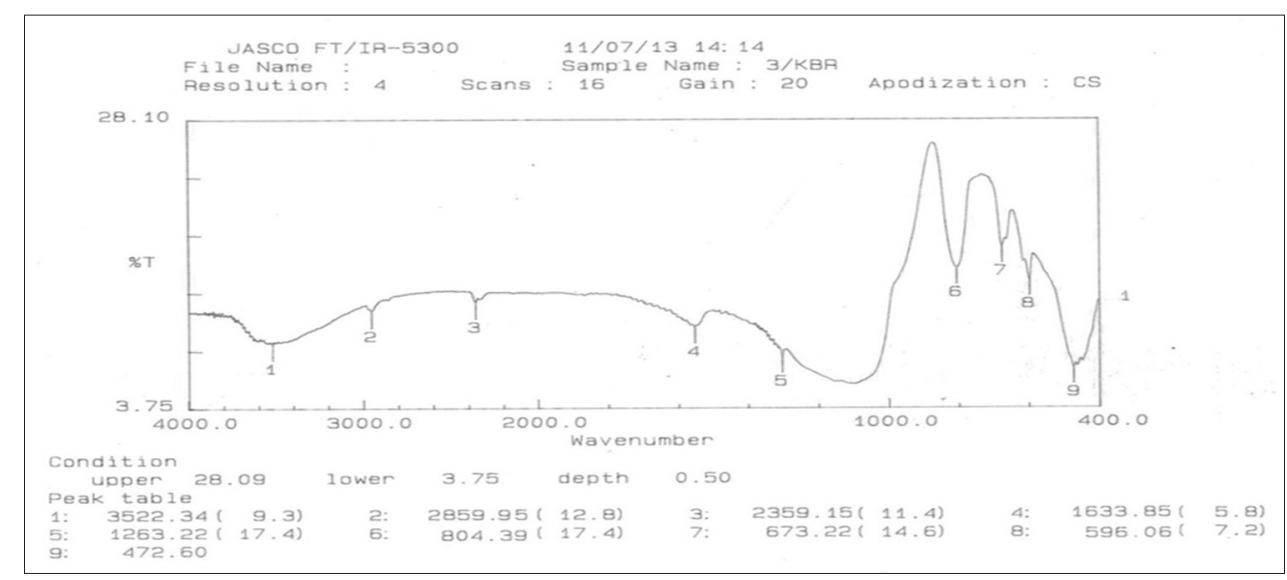

Figure 1: Infrared spectrum of 1, 2, 3, 9-tetrahydropyrrolo quinazoline-3, 7-diol

double-distilled water. Then, the leaves were allowed for drying in shade and aerated at room temperature. The airdried leaves are pulverized using the mechanical grinder. This extract was prepared using Soxhlet apparatus. About $150 \mathrm{~g}$ of dried leaves powder was taken in a muslin cloth bag. The purified ethyl acetate was passed through the tube where the powder bag was kept. The ethyl acetate was passed through siphon tube until it reached the round-bottom flask in which porcelain chips were provided. The vapors containing the constituents passed through the condenser and reached the tube containing powder bag, and the process was repeated. This was continued for $24 \mathrm{~h}$. Then, the round-bottom flask containing extract was transferred to a beaker and was allowed to evaporate in a water bath. This concentrated ethyl acetate extract was stored at room temperature, and it is used for further analysis. 


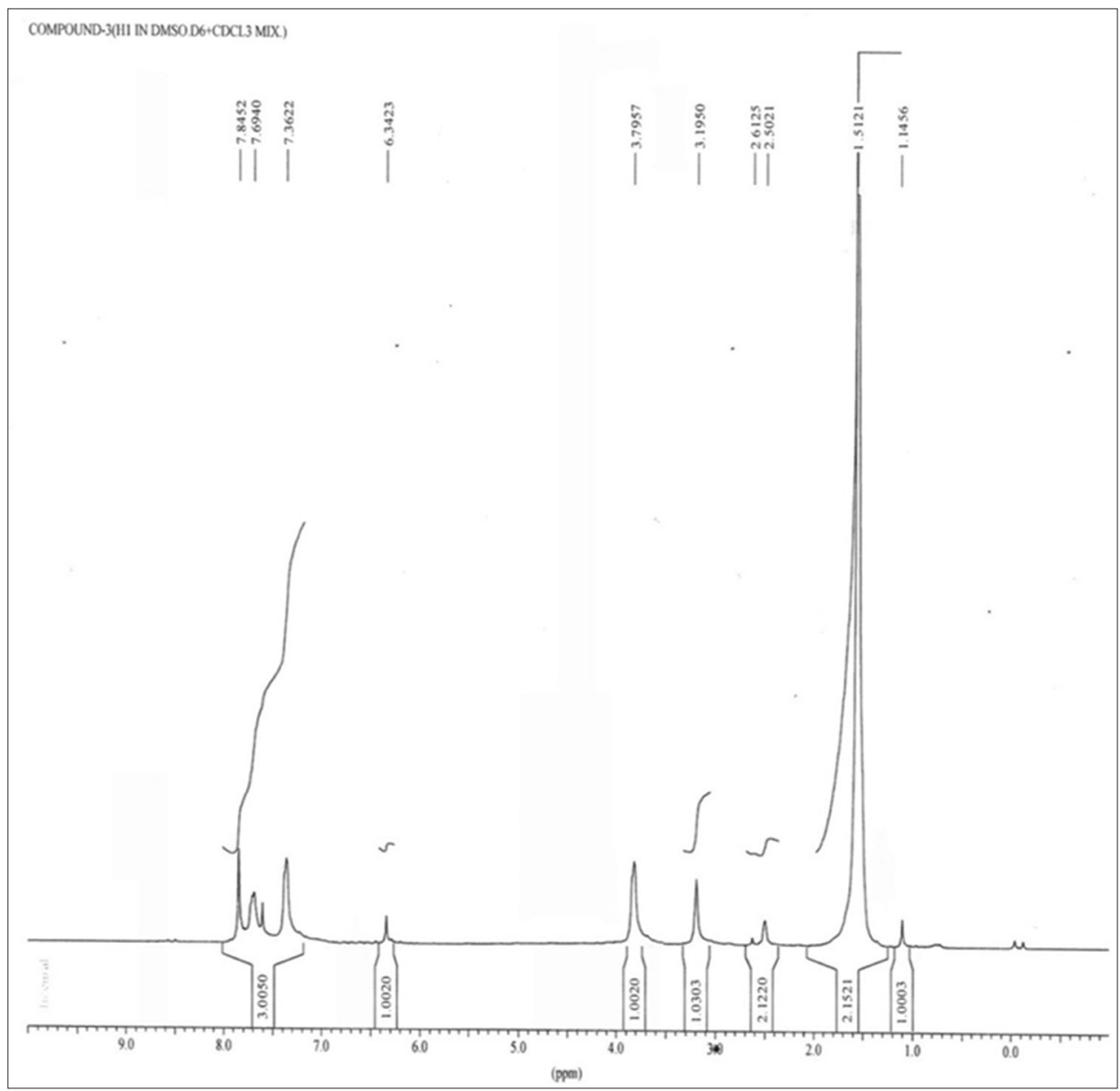

Figure 2: ${ }^{1} \mathrm{H}$ NMR spectrum of 1, 2, 3, 9-tetrahydropyrrolo quinazoline-3, 7-diol

\section{Composition Analysis}

A Fourier-transform infrared (FT-IR) is carried out in an instrument of JASCO 5300, analyzed using pressed pellet technique for different wave number identifications. Nuclear magnetic resonance (NMR) was carried out by VarianNMR-600 spectrometer using tetramethylsilane as an internal standard. Standard pulse sequences were used for homo- and heteronuclear correlation experiments. ${ }^{1} \mathrm{H}$ NMR spectra were measured at $599 \mathrm{MHz}$, whereas ${ }^{13} \mathrm{CNMR}$ spectra were run at 150 MHz. Multiplicities of ${ }^{13} \mathrm{C}$ NMR resonances were determined by Distortionless enhancement through polarization transfer (DEPT). Liquid chromatography-mass spectrometry (LCMS) analyses were carried out with a quadrupole ion trap MS (SHIMADZU). The stationary phase was used as the type of $\mathrm{C} 18$ column $(250 \times 4.6 \mathrm{~mm})$ manufactured by Waters Column, Bengaluru, India. The mobile phase constitutes the Solvent A: 5\% formic acid in water and Solvent B: Methanol (high-performance liquid chromatography [HPLC] Grade). The ultraviolet (UV) response during LC-MS was monitored at $360 \mathrm{~nm}$, the highest absorbance wavelength for each set of components as determined from prior HPLC studies. The LC-MS was operated in the positive operating mode using electron spray ionization source.

\section{Hot plate method ${ }^{[5,6]}$}

Mice of either sex weighing between $20 \mathrm{~g}$ and $25 \mathrm{~g}$ were kept on hot plate $\left(55 \pm 0.5^{\circ} \mathrm{C}\right)$, and the time for fore paw licking or jumping was taken as reaction time. Mice showing reaction time before $5 \mathrm{~s}$ were selected. Animals not responding in this period were discarded. The selected animals were divided into six groups. Each animal of the groups received one of the following $2 \% \mathrm{w} / \mathrm{v}$ of gum acacia $(2 \mathrm{ml} / \mathrm{kg}$ ) in normal saline, pentazocine $(30 \mathrm{mg} / \mathrm{kg})$, ethyl acetate extract $(100 \mathrm{mg} / \mathrm{kg}$ and $200 \mathrm{mg} / \mathrm{kg})$, and ethanol extract $(100 \mathrm{mg} / \mathrm{kg}$ and $200 \mathrm{mg} / \mathrm{kg})$ intraperitoneally. Analgesia was assessed with Eddy's Hot Plate Apparatus (Analgesiometer) paw licking or jumping was measured initially, and another set of three measures was taken as 30,60 , and $120 \mathrm{~min}$ interval. A cutoff period of $15 \mathrm{~s}$ was observed to avoid damage of paws.

\section{Tail flick method ${ }^{[7,8]}$}

Before the study, Swiss albino mice (20-25 g) were screened for sensitivity test by placing the tip of the tail on the radiant heat source. Any animal that held to withdraw its tail in $5 \mathrm{~s}$ was rejected from the study. The selected 


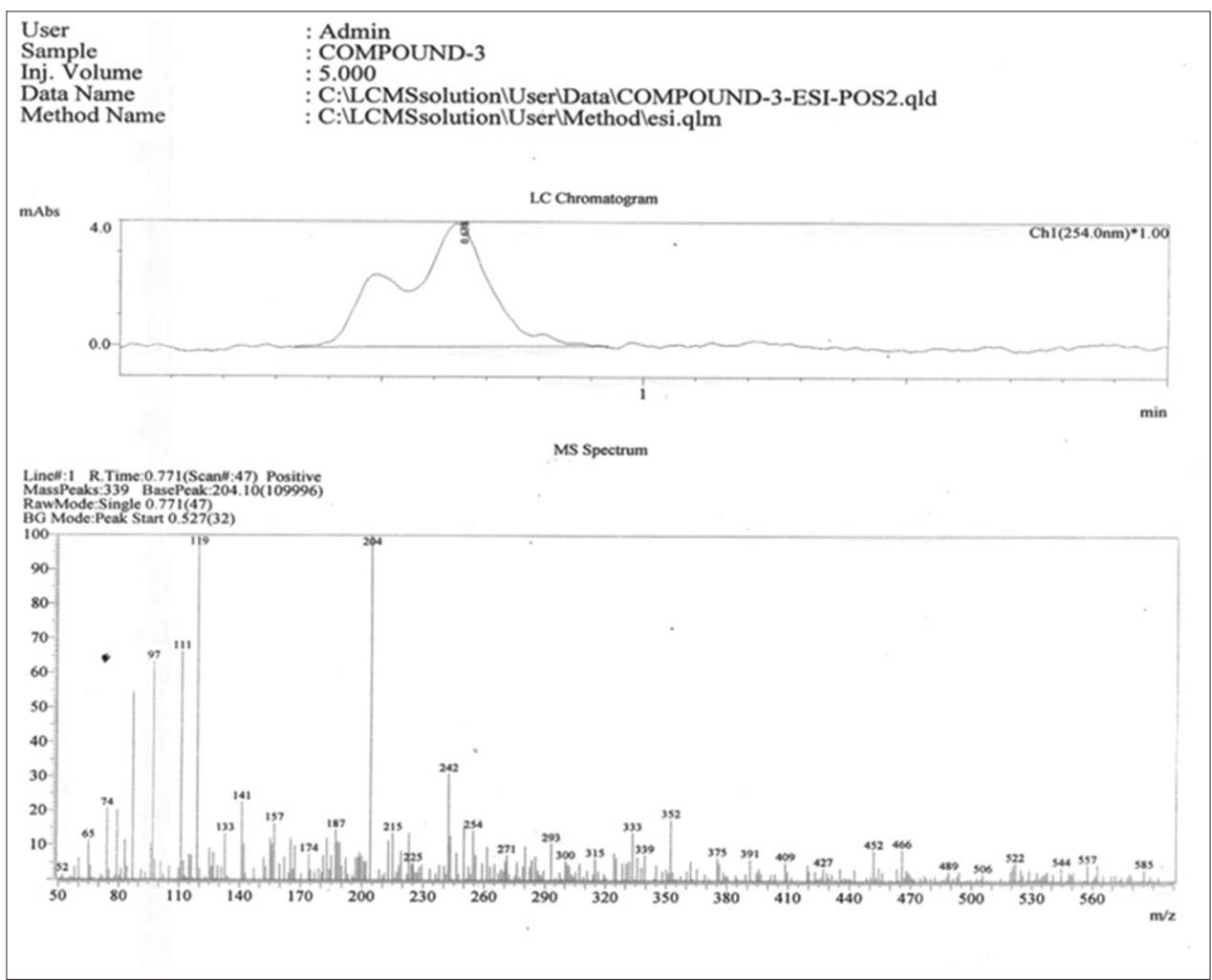

Figure 3: Liquid chromatography-mass spectrometry of 1, 2, 3, 9-tetrahydropyrrolo quinazoline-3, 7-diol

animals were divided into six groups. Each animal of the groups received one of the following $2 \% \mathrm{w} / \mathrm{v}$ of gum acacia $(2 \mathrm{ml} / \mathrm{kg})$ in normal saline, pentazocine $(30 \mathrm{mg} / \mathrm{kg})$, ethyl acetate extract $(100 \mathrm{mg} / \mathrm{kg}$ and $200 \mathrm{mg} / \mathrm{kg})$, and ethanol extract $(100 \mathrm{mg} / \mathrm{kg}$ and $200 \mathrm{mg} / \mathrm{kg})$ intraperitoneally. Analgesia was assessed with the Tail Flick apparatus (Analgesiometer). The basal reaction time was measured initially, and another set of three measures was taken as 30,60 , and 120 min interval and the reaction of animals consider as the post-drug reaction time. A cut of period of $10 \mathrm{~s}$ was observed to prevent tissue damage of the tail of the animals.

\section{RESULTS AND DISCUSSION}

To confirm the structure of the major compounds, ethyl acetate leaf extract was studied by $1 \mathrm{H}-\mathrm{NMR}$ technique. The chemical shift of the obtained NMR spectra was analyzed with those of the standard spectra of pure compounds with the help of laboratory-made software. The spectral parameters such as the concentration, low power decoupling, and temperature are in optimized conditions to provide good accuracy of the method. The present method allows for precise identification of major compounds present in the leaves. The compounds of 1,2,3,9-tetrahydropyrrolo quinazoline-3,7-diol and 3,7-dimethyloct-6-en-1-ol are identified [Figure 1]. The method is very well suited for the isolation of the major components which was listed as follows:

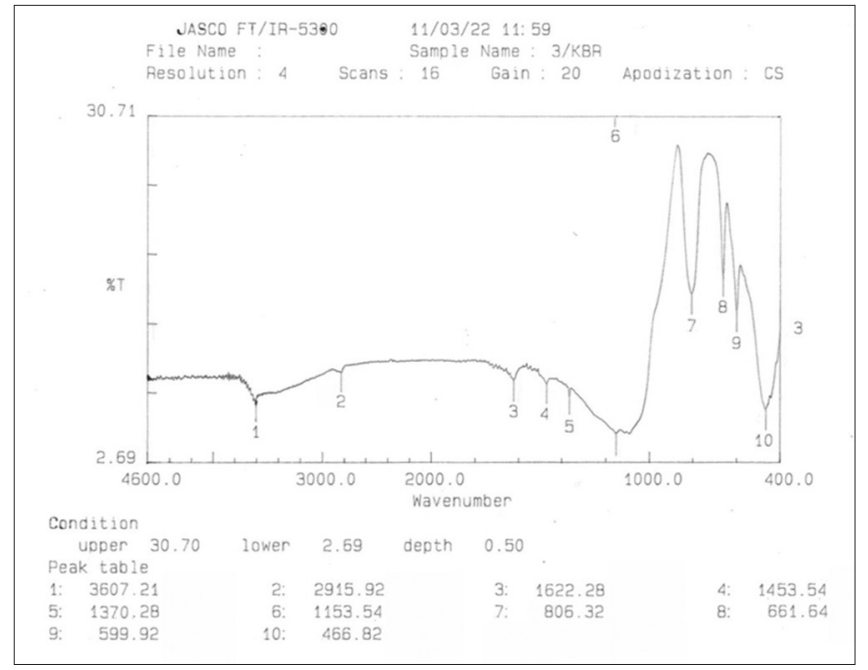

Figure 4: Infrared spectrum of 3, 7-dimethyloct-6-en-1-ol

\section{Compound: 1}<smiles>Oc1ccc2c(c1)CN1CCC(O)C1=N2</smiles>

1,2,3,9-tetrahydropyrrolo quinazoline-3,7-diol

Infrared (IR) Values: $3522.34(\mathrm{O}-\mathrm{H}), 2859.95(\mathrm{C}-\mathrm{H}), 2359.15$ $(\mathrm{C}=\mathrm{N}), 1633.85(\mathrm{C}=\mathrm{C}), 1263.22(\mathrm{C}-\mathrm{N})$. 
1H NMR Signals: $3 \mathrm{H}$ multiplet $7.845-7.362$ referred to aromatic ring, $1 \mathrm{H}$ singlet with 6.342 referred to aromatic $\mathrm{OH}$ group, $2 \mathrm{H}$ duplet 2.612-2.502 referred to aromatic $\mathrm{CH}_{2}$ group, $2 \mathrm{H}$ singlet with 1.512 referred to $\mathrm{CH}_{2}$ group, $2 \mathrm{H}$ singlet with 3.79 referred to $\mathrm{CH}_{2}$ group, and two $1 \mathrm{H}$ singlets 3.195 referred to $\mathrm{CH}$ group and 2.21 referred to $\mathrm{OH}$ group [Figure 2].

LC-MS m/z: $204.08\left(\mathrm{C}_{11} \mathrm{H}_{12} \mathrm{~N}_{2} \mathrm{O}_{2}\right)$

\section{Compound: 2}

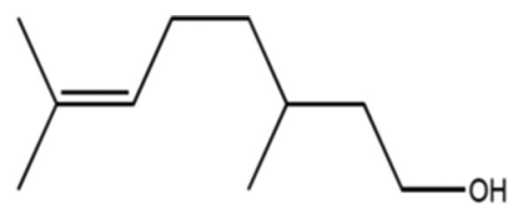

\section{3,7-dimethyloct-6-en-1-ol}

IR Values: $3607.21(\mathrm{O}-\mathrm{H}), 2915.92(\mathrm{C}-\mathrm{H}), 1622.28(\mathrm{C}=\mathrm{C})$, $1453.54\left(\mathrm{CH}_{2}\right), 1370.28\left(\mathrm{CH}_{3}\right), 1153.54(\mathrm{C}-\mathrm{O})$.

1H NMR Signals: A signal of $6 \mathrm{H}$ singlet $1.777 ; 3 \mathrm{H}$ singlet 1.06; four $2 \mathrm{H}$ singlets $1.29,1.4,1.96$, and 3.11; and three $1 \mathrm{H}$ singlets with 6.927 referred to $\mathrm{OH}$ group, 5.267 referred to $\mathrm{CH}$ group, and 1.65 referred to $\mathrm{H}$ directly attached to carbon group.

\section{LC-MS m/z: $156.15\left(\mathrm{C}_{10} \mathrm{H}_{20} \mathrm{O}\right)$.}

Pain is centrally modulated through a number of complex processes including opioid, dopaminergic, descending noradrenergic, and serotonergic systems.$^{[9,10]}$ The hot-plate and tail flick tests were useful in elucidating centrally mediated anti-nociceptive responses, which focuses mainly on changes

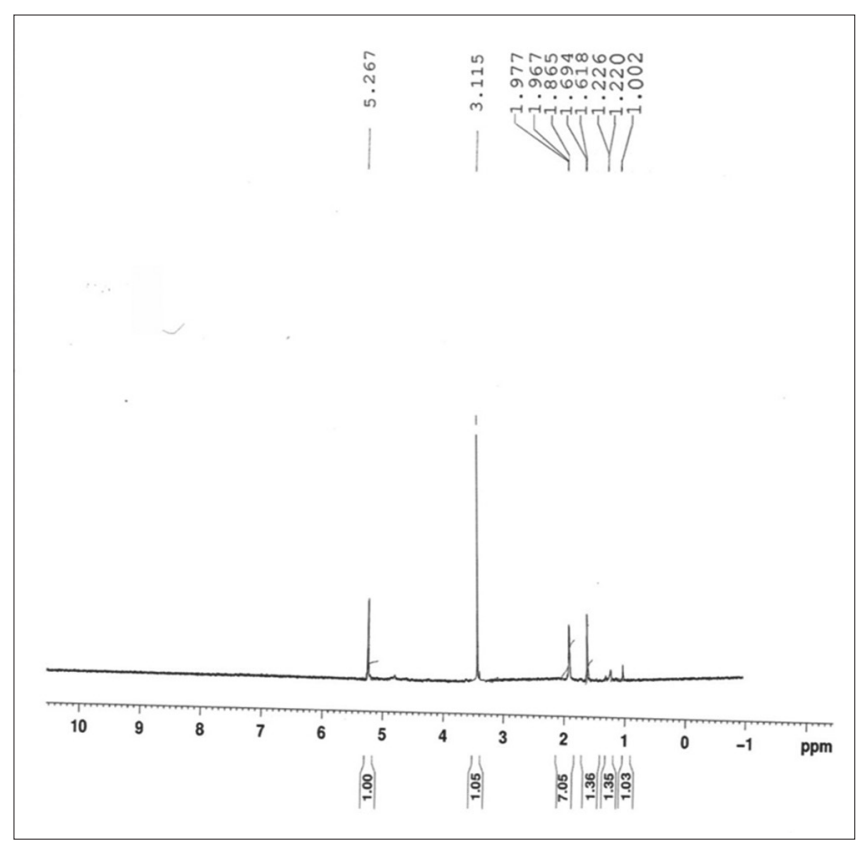

Figure 5: ${ }^{1} \mathrm{H}$ NMR spectrum of 3, 7-dimethyloct-6-en-1-ol above the spinal cord level. ${ }^{[1]]}$ The hot-plate method and tail flick test are considered to be selective to examine compounds acting through opioid receptor. Narcotic analgesics inhibit both peripheral and central mechanism of pain, while nonsteroidal anti-inflammatory drugs inhibit only peripheral pain. It also reported that the inhibition of pain could arise not only from the presence of opioids and/or opiodiomimetics but could also arise from the presence of phenolic constituents ${ }^{[12]}$ and steroidal constituents [Figure 3]. It may be due to the similar type of constituents present in the $T$. capensis leaf extracts which exhibited the analgesic activity.

The phytoconstituents such as flavonoids, tannins, and alkaloids have been reported in several analgesic literatures as possible to produce analgesic effect. The presence of flavonoids in ethyl acetate extract of $T$. capensis leaves may contribute for the analgesic activity. Ethyl acetate extract of $T$. capensis leaves increased mean basal latency which indicates that it may act through centrally mediated analgesic mechanism. Isolated compounds showed an increase in the basal reaction time significantly in dose- and time-dependent manner to the thermal stimulus [Figure 4]. Activity may be produced due to the two compounds present in the extract. Pain is a sensorial modality representing the only symptom for the diagnosis of several diseases. It often has a protective function [Figure 5].

Throughout history, man has used many different forms of therapy for the relief of pain, among them; medicinal herbs are highlighted due to their wide popular use [Figure 6]. In the relief of pain, opiates are generally considered to act on the central nervous system exerting their effects through three opioid receptors $(\mu, \kappa$, and $\delta$ ), and such drugs are, especially, important for the treatment of chronic pain. Although morphine has reigned for centuries as the king of painkillers, its rule has not been totally benign. There are concerns about its addictive properties and side effects, which include respiratory depression, drowsiness, decreased gastrointestinal motility, nausea, and several alterations of the endocrine and autonomic nervous systems. ${ }^{[1]]}$

- In Eddy's hot plate method, ethyl acetate extract of T. capensis leaves showed a significant $(P<0.05)$ analgesic activity when compared to control and comparable to that of standard.

- Extract exhibited marked central analgesic effect as evidence by a significant increase in mean latency time compared to control.

- Both compounds isolated from ethyl acetate extract showed an increase in the mean latency time significantly in dose- and time-dependent manner to the thermal stimulus.

- Comparing both 3,7-dimethyloct-6-en-1-ol and 1,2,3, 9-tetrahydropyrrolo quinazoline-3, 7-diol compounds, 3 , 7-dimethyloct-6-en-1-ol showed a comparable activity to standard.

- Ethyl acetate extract of T. capensis leaves showed a 


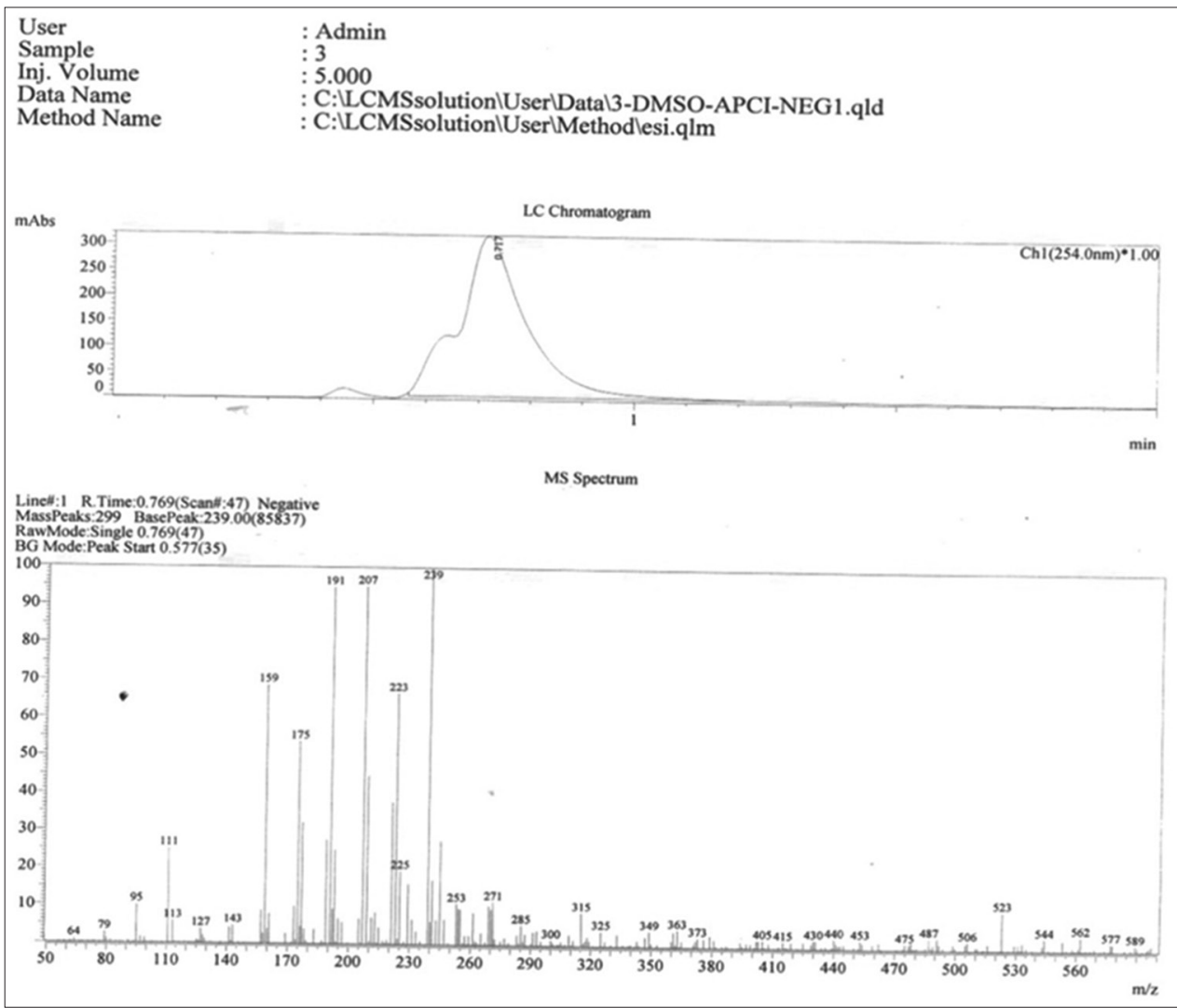

Figure 6: Liquid chromatography-mass spectrometry of 3, 7-dimethyloct-6-en-1-ol

significant $(P<0.001)$ analgesic activity when compared to the control and comparable to that of standard [Table 1].

- Extract exhibited marked central analgesic effect as evidence by a significant increase in basal reaction time comparable to control.

- In tail flick method same as like Eddy's hot plate method, both compounds showed an increase in the basal reaction time significantly in dose- and time-dependent manner to the thermal stimulus [Table 2].

- Comparing both 3, 7-dimethyloct-6-en-1-ol and 1, 2, 3, 9-tetrahydropyrrolo quinazoline-3, 7-diol compounds, 3, 7-dimethyloct-6-en-1-ol showed a comparable activity to standard.

\section{Analytical Profile of Isolated Compounds}

\section{Compound no: 01 (1, 2, 3, 9-tetrahydropyrrolo quinazoline-3, 7-diol)}

IR $\mathrm{V}_{\max }(\mathrm{KBr}) \mathrm{cm}^{-1} 3522.34,2859.95,2359.15,1633.85$, 1263.22;

Its IR values showed the following functional groups: $3522.34(\mathrm{O}-\mathrm{H}), 2859.95(\mathrm{C}-\mathrm{H}), 2359.15(\mathrm{C}=\mathrm{N}), 1633.85$ $(\mathrm{C}=\mathrm{C}), 1263.22(\mathrm{C}-\mathrm{N})$

${ }^{1} \mathrm{H}$ NMR (סppm): 7.845-7.362 (3H, m), $6.342(1 \mathrm{H}, \mathrm{s})$, $3.796(1 \mathrm{H}, \mathrm{s}), 3.195(1 \mathrm{H}, \mathrm{s}), 2.612-2.502(2 \mathrm{H}, \mathrm{d}), 1.512(2 \mathrm{H}, \mathrm{s})$, and $1.145(1 \mathrm{H}, \mathrm{s})$;
Its ${ }^{1} \mathrm{H}$ NMR displayed a signal of $3 \mathrm{H}$ multiplet 7.845-7.362 referred to aromatic ring, $1 \mathrm{H}$ singlet with 6.342 referred to aromatic $\mathrm{OH}$ group, $2 \mathrm{H}$ duplet 2.612-2.502 referred to aromatic $\mathrm{CH}_{2}$ group, $2 \mathrm{H}$ singlet with 1.512 referred to $\mathrm{CH}_{2}$ group, $2 \mathrm{H}$ singlet with 3.79 referred to $\mathrm{CH}_{2}$ group, and two $1 \mathrm{H}$ singlets 3.195 referred to $\mathrm{CH}$ group and 2.21 referred to OH group.

LC-MS m/z: 204.08 (calculated for $\mathrm{C}_{11} \mathrm{H}_{12} \mathrm{~N}_{2} \mathrm{O}_{2}$, 204.22).

\section{Compound no: 02 (3, 7-dimethyloct-6-en-1-ol)}

IR $\mathrm{V}_{\max }(\mathrm{KBr}) \mathrm{cm}^{-1} 3607.21,2915.92,1622.28,1453.54$, 1370.28, 1153.54.

IR values showed the following functional groups: 3607.21 $(\mathrm{O}-\mathrm{H}), 2915.92(\mathrm{C}-\mathrm{H}), 1622.28(\mathrm{C}=\mathrm{C}), 1453.54\left(\mathrm{CH}_{2}\right)$, $1370.28\left(\mathrm{CH}_{3}\right)$, and $1153.54(\mathrm{C}-\mathrm{O})$.

${ }^{1} \mathrm{H} \quad \mathrm{NMR}(\delta$ ppm): $5.267(2 \mathrm{H}, \mathrm{s}), \quad 3.115(2 \mathrm{H}, \mathrm{s}), \quad 1.977-$ $1.865(10 \mathrm{H}, \mathrm{m}), 1.656(2 \mathrm{H}, \mathrm{d}), 1.223(2 \mathrm{H}, \mathrm{d})$, and $1.002(2 \mathrm{H}, \mathrm{s})$;

Its ${ }^{1} \mathrm{H}$ NMR displayed a signal of $6 \mathrm{H}$ singlet $1.777 ; 3 \mathrm{H}$ singlet 1.06; four $2 \mathrm{H}$ singlet $1.29,1.4,1.96$, and 3.11 ; and three $1 \mathrm{H}$ singlets with 6.927 referred to $\mathrm{OH}$ group, 5.267 referred to $\mathrm{CH}$ group, and 1.65 referred to $\mathrm{H}$ directly attached to carbon group.

LC-MS m/z: 156.15 (calculated for $\mathrm{C}_{10} \mathrm{H}_{20} \mathrm{O}, 156.265$ ). 


\section{CONCLUSION}

The present study revealed that ethyl acetate extract of leaves of $T$. capensis has significant analgesic activity. Further isolated compounds had also shown effective analgesic activity. Hence, it may be concluded that the isolated quinone derived from lapachol (a naphthoquinone) may be responsible for few of the therapeutic potential of the studied extract. Further studies are to be warranted for its safety, efficacy, and mechanism of action for its therapeutic potential.

\section{ACKNOWLEDGMENT}

The authors would like to thank the authority of K L College of Pharmacy, KLEF Deemed to be University, and the supporters those who helped in completing the work in time.

\section{REFERENCES}

1. Amaral L, Viveiros M, Kristiansen JE. Phenothiazines: Potential alternatives for the management of antibiotic resistant infections of tuberculosis and malaria in developing countries. Trop Med Int Health 2001;6:1016-22.

2. Roberts M. Indigenous Healing Plants. South Africa: Halfway House; Southern Book Publishers; 1990.

3. Hutchings A, Scott AH, Lewis G. Antony Balfour Cunningham. Zulu Medicinal Plants: Inventory. Pietermaritzburg: University of Natal Press; 1996.

4. Pillay P, Maharaj VJ, Smith PJ. Investigating South
African plants as a source of new antimalarial drugs. J Ethnopharmacol 2008;119:438-54.

5. Jain KP, Soni P, Upmanyu N, Shivhare Y. Evaluation of analgesic activity of Manilkara Zapota (Leaves). Eur J Exp Biol 2011;1:14-7.

6. Lalitha KG, Venkatachalam T, Rathinavel G, Kumar VK, Kalaiselvi P, Evaluation of analgesic activity of Evodialunu ankenda (Gaertn) Merr. Bark Der Pharm Sin 2010;1:7-10.

7. Surbhi Gupta, Analgesic activity of aqueous extract of Musa paradisiacal. Der Pharm Sin 2011;2:74-7.

8. D'Amour FF, Smith GL. A method for determining loss of pain sensation. J Pharmacol Exp Ther 1941;72:74-9.

9. Rolland A, Fleurentin J, Lanhers MC, Younos C, Misslin R, Mortier F, et al. Behavioural effects of the American traditional plant Eschscholzia californica: Sedative and anxiolytic properties. Planta Med 1991;57:212-6.

10. Headley PM, O'Shaughnessy CT. Evidence for opiate and dopamine interaction instriatum. Br J Pharmacol 1985;86:700.

11. Vongtau HO, Abbah J, Mosugu O, Chindo BA, Ngazal IE, Salawu AO, et al. Antinociceptive profile of the methanolic extract of Neorautanenia mitis root in rats and mice. J Ethnopharmacol 2004;92:317-24.

12. Elisabetsky E, Amador TA, Albuquerque RR, Nunes DS, Carvalho Ado C. Analgesic activity of Psychotria colorata (Willd. Ex R. and amp; S.) Muell. Arg. Alkaloids. J Ethnopharmacol 1995;48:77-83.

Source of Support: Nil. Conflict of Interest: None declared. 